\title{
THE IMPACT OF SWITCHING COSTS ON CUSTOMER LOYALTY: A STUDY AMONG CUSTOMERS OF MOBILE TELEPHONY
}

\author{
Allan Ricki ${ }^{1}$; Andreas Raharso ${ }^{2}$
}

\begin{abstract}
The conditions for doing business are changing rapidly. In last few years the mobile telecom market has witnessed a substantial growth and rapid changes globally as well as domestically. Customer loyalty is a critical issue in the success of any business system, for this reason, the main condition for protecting the subscriber base is to win customer loyalty, a key necessity for the maintenance of a brand's life in the long term. To achieve this aim, customer loyalty must be measured and "switching costs" identified. The latter render subscribers' preference for rival operator more expensive. In this connection, this study aim is to measure the impact of switching costs on customer loyalty, and the direct and indirect of "switching costs" on customer loyalty.

For doing so, a survey has been performed on customers of the prepaid and postpaid mobile service operator in Indonesia, questionnaire were distributed among them and the results analyzed base upon the proposed research questions and hypotheses, and finally the conclusions and implications were made.
\end{abstract}

Keywords: switching costs, customer loyalty, mobile telephony, consumer behavior.

\footnotetext{
1,2 BINUS BUSINESS SCHOOL, BINUS UNIVERSITY, JWC Campus, Jl. Hang Lekir I No. 6, Kebayoran Baru, South Jakarta 12120, graharso@hotmail.com
} 


\section{INTRODUCTION}

Industrial of cellular phone has been rapid growth in the last of two decade. Even in developed countries or in developing countries. In Indonesia, cellular phone has been radically changing the mapping of telecommunication industrial. Which is in the past, phone was one of a luxury thing, with the intention that only certain groups which can enjoying it. But now we can get it without any problems and their price is usually cheap than in the past, even in fixed line wire line or in fixed line wireless and mobile phone. The entire people have an access to use telecommunications service to various needs, either commerce business, family or other need. And so does all walks of life from elite to house assistant, from metropolis until villagers in all Indonesia can access existing telecommunications service. Moreover the government used the universal service obligation (USO) during the recent years. With the intention that the telecommunication service activities brought to purilieus, though its result still not yet gratified.

Table 1. The Growth Amount of Customer Cellular Phone In Indonesia

\begin{tabular}{|c|c|c|c|}
\hline Years & $\begin{array}{l}\text { Amount of Customer } \\
\text { (Thousand) }\end{array}$ & Growth (\%) & Telendensitas Cellular / 100 \\
\hline 1996 & 563 & & 0.3 \\
\hline 1997 & 916 & 62.7 & 0.5 \\
\hline 1998 & 1066 & 16.4 & 0.5 \\
\hline 1999 & 2155 & 102.2 & 1 \\
\hline 2000 & 3509 & 62.8 & 1.7 \\
\hline 2001 & 6394 & 82.2 & 3.1 \\
\hline 2002 & 11273 & 76.3 & 5.3 \\
\hline 2003 & 18494 & 64.1 & 8.6 \\
\hline 2004 & 30337 & 64.0 & 13.6 \\
\hline 2005 & 46910 & 54.6 & 21.1 \\
\hline 2006 & 54370 & 15.9 & 24.4 \\
\hline
\end{tabular}

Recently we see emulation which progressively tightens between operator in drawing consumer to be interesting to use their product, especially for the fixed line of wireless or cellular. Even in a few media we see a price combat to draw a user by various operator, so that there's offering free sms and or free conversation utilize to draw consumer. So the smart society or smart consumer also exploiting the price war to get cheap price with change the operator or have some service from some operator. Therefore the cellular phone market in Indonesia estimated to have the highest level of monthly rotation in the world. An Indonesian cellular customer is too easy to change their number to the other operator. This issue is not quit of emulation between telecommunications operator in Indonesia. The number of rotation of cellular customer in Indonesia is estimated to reach $8,6 \%$ in a month. While the number of customer rotation in India is about $4 \%$ per month, Malaysia 3,7 \% per month, Philipina 3,1\% per month, Thailand 2,9\% per month, Chinese 2,7\% per month, and Bangladesh 2,1 \% per month ( Tempo, 2007). The growth in telecommunications industry is influenced through the 
growth from seluler market. Where since early its growth, the cellular product is differ from fixed line phone remain to with monopolistic cable network by PT Telkom. Whereas cellular phone since early have no resistance come on the market to enthusiastic operator in this business, so that emulation between operators in this venomous market enough, and even recently turned to a price war. Until this time in Indonesia have attended 10 operator that is Telkom, Telkomsel, Indosat, Excelcomindo (XL), Hutchison (3), Sinar Mas Telecom,Sampoerna Telecommunication, Bakrie Telecom (Esia), Mobile-8 (Fren), and Natrindo Phone Cellular (previous of Lippo Telecom). From this amount, customers fixed line is about 9 million and cellular cutomers is around 64 million in the year 2006. If we divided pursuant to used platform, GSM cellular user is counted $88 \%$, Cellular CDMA $3 \%$, and CDMA fixed wireless access (FWA) $9 \%$. But from that ten operators only 3 operator owning market share more than 5\% that is Telkomsel, Indosat and Excelcomindo. This issue because emulation storey level between operators in Indonesia has been improved and the entire customer also enjoying the benefit from the emulation.

Table 2. Cellular Phone Market Share in Indonesia (2006).

\begin{tabular}{|l|l|l|r|r|}
\hline Operator (s) & Product & Technology & $\begin{array}{l}\text { Amount of } \\
\text { Customers } \\
\text { (Million) }\end{array}$ & $\begin{array}{l}\text { Market } \\
\text { Share } \\
(\%)\end{array}$ \\
\hline PT. Telkomsel & $\begin{array}{l}\text { Halo, Simpati, Kartu } \\
\text { As }\end{array}$ & $\begin{array}{l}\text { GSM } \\
900 / 1800\end{array}$ & 35,6 & 55,6 \\
\hline PT. Indosat & Matrix, Mentari, IM3 & $\begin{array}{l}\text { GSM } \\
900 / 1800\end{array}$ & 15,9 & 24,8 \\
\hline PT. Exelcomindo & Xplor, Jempol, Bebas & $\begin{array}{l}\text { GSM } \\
\text { 900/1800 }\end{array}$ & 9,5 & 14,8 \\
\hline PT. Bakrie Telecom & Esia, Ratelindo & CDMA 2000 & 1,6 & 2,5 \\
\hline PT. Mobile-8 Telecom & Fren & CDMA & 1,4 & 2,2 \\
\hline PT. Natrindo Seluler & Natrindo & GSM 1800 & - & $<0,5$ \\
\hline $\begin{array}{l}\text { PT. Sampoerna } \\
\text { Telekom }\end{array}$ & Sampurna & CDMA 450 & - & $<0,5$ \\
\hline $\begin{array}{l}\text { PT. Pasifik Satelit } \\
\text { Nusantara }\end{array}$ & PSN & $\begin{array}{l}\text { GSM/AMPS } \\
\text { Satelite }\end{array}$ & - & $<0,5$ \\
\hline
\end{tabular}

Source : Nathan dan Atmitra

Reffering from data that describe before, we can make an assumption that customer loyalty is one of the important key in marketing and there's four elements of loyalty, customer retention, repurchase, long-term customer relationships and profitability (Reichheld And Sasser 1990). Differentiating between customer retention and customer loyalty is important, which customer retention is a strategy that firm implements and customer loyalty as a psychological situation the customer has or has not. Word-of-mouth has a huge benefit over other types of promotion in terms of integrity and customer loyalty is capable to produce it. It is recognized to give confidence of argument to counter-persuasion, retention and therefore not as good as churn tariff. In the end of differentiating customer retention and customer loyalty mean stronger loyal customers and market share with a straight optimistic result on the bottoms line. 
A number of academic disciplines, first and foremost in marketing, strategy and economic has long been researched and documented the model of customer switching costs (Burnham, Frels, Mahajan 2003; Klemperer 1987; Porter 1980). Research has specifies that customer switching costs are becoming even extra strategic in the progressively more networked competitive surroundings (Shapiro and Varian 1999) and they are acknowledged as a basics key in achieving competitive development. A cost that put off customers from switching to a competitor's manufactured goods or service difined as switching costs in commonly. Customer switching costs are recognized to be one of the solution sets of antecedents to customer loyalty and their meaning is highlighted in the literature (Bateson And Hoffman 1999; Lee And Feick 2001; Oliver 1996). Firms are more likely to challenge to keep their market share by focusing on retaining existing customers either market growth slows or markets develop into more aggressive. Customer retention has been supporting as an easier and more dependable resource of better-quality performance (Fornell and Wernerfelt, 1987; Peters, 1988; Reichheld and Sasser, 1990). Firms begin a variety of activities, including programs on customer satisfaction to improve customer retention (Anderson and Sullivan, 1993; Rust and Zahorik, 1993; Anderson et al., 1994; Jones and Sasser, 1995), loyalty (Reichheld, 1996; Dowling and Uncles, 1997) and complaint management (Hirschman, 1970; Fornell and Wernerfelt, 1987). Researchers have paid particular concentration to the management of service quality to understanding customer satisfaction: explaining the impact of service quality on revenue (Rust et al., 1995; Zeithaml et al., 1996), and developing strategies to gather customer expectations (Parasuraman et al., 1988). The researchers have focused on the progression in which customers form expectations of service, recognize service performance, and then decide to remain with or switch providers. In addition, the researchers have looked up the performance implications of investments in improving service quality and customer retention. In clearing up the relation between customer satisfaction and loyalty, a small number of studies in marketing have examined the role of switching costs. Switching costs are costs that the consumer must release because of switching or migrating to another provider or they would not incur if they stayed with their current provider. In marketing, Fornell (1992) was one of the earliest authors that think about switching costs: adding the switching cost to customer satisfaction in the customer loyalty function. Lately, Jones and Sasser (1995) mentioned switching costs as a single reason that determines the competitiveness of market environment, in view of the fact that high switching costs discourage changing from a current provider, thereby yielding less incentive for firms actively to compete. In the presence of switching costs, ex ante homogeneous products or services, expressly, functionally identical services develop into ex post heterogeneous (Klemperer, 1987). As a result, experimental customer loyalty possibly due to satisfaction or it may be due to dissatisfaction in a product category in which moderately high switching costs make it difficult for consumers to change providers.

A variety of classifications of defectors have been put ahead. For example, Keaveney (1995), who studied switching resulting from serious incidents in service firms, identifies eight common categories of explanation for customers switching: core service failure $(26 \%)$; failed service encounters (21\%); price (17\%); response to failed service $(11 \%)$; inconvenience (10\%); competition (4\%); ethical problems $(4 \%)$; and involuntary switching $(2 \%)$. More willingly than just present a typology of churn, a more exciting view is to realize the role of unusual switching costs in the progression leading to the result. It is important both 
from a theoretical and a managerial perspective to clarify the concepts of switching costs and customer loyalty and to identify their dimensions and empirically seek to determine their intereffect.

\section{STATEMENT OF PROBLEM}

It is important both from a theoretical and a managerial perspective to clarify the concepts of switching costs and customer loyalty and to identify their dimensions and empirically seek to determine their inter-effect. The study develops and investigates hypotheses, while data are collected from a sample of corporate customers of a mobile phone company.

\section{SWITCHING COSTS and CUSTOMER LOYALTY}

Porter (1980) and Burnham, Frels and Mahajan (2003) suggested that switching cost are "the one time costs that customer relate with the route of switching from one product or service to another". While switching costs must be linked among the switching procedure, they must not be incurred instantly upon switching. In addition, switching costs need not be restricted to objective, "economic" costs. When consumer simplistically state that "it's just not worth it" to switch source, they may distinguish impediments ranging from "search costs, transaction costs, learning costs, loyal customers discount, customer habit, emotional cost and cognitive effort, coupled with financial, social and psychological risk on the part of buyer" (Fornell 1992). These costs are infrequently openly assessed, but they turn out to be most important and evident when consumers are faced with a reason to think about switching.

And Burnham, Frels and Mahajan (2003) identify three types of switching costs as a transaction costs, learning costs and contractual costs. Transaction costs are costs that happen when starting a new association with a provider and occasionally also include the required to terminate an existing relationship. Learning costs represent the effort required by the customer to achieve the equal stage of comfort of familiarity acquired of using an item for consumption but which may not be transferable to additional brands of the same product. Contractual costs are directly firm-induced in regulate to penalize switching by customers. It includes examples such as repeat-purchase, discounts or rewards and many flyer programmes. Contractual

switching cost can also be created while the customer signs an undertaking to remain loyal for a sure period of time or give an exit consequence.

There are many definitions of both satisfaction and loyalty in the literature; a perusal of these reveals, however, that they are process definitions. That is, they define what consumers do to become satisfied and/or loyal. For example, satisfaction has been defined as an "evaluation of the perceived discrepancy between prior expectations and the actual performance of the product" (Tse and Wilton 1988; see also Oliver 1980). Generally, loyalty has been and continues to be defined in some circles as repeat purchasing frequency or relative volume as same brand purchasing (e.g., Tellis 1988). Of note is a definition created by Newman and Werbel (1973), which defined loyal customers as those who rebought a brand, considered only that brand and did no brand related information seeking. All these definitions 
suffer from the problem that they record what the consumer does. None taps into the psychological meaning of satisfaction or loyalty.

In Oliver research (1997). Satisfaction is defined as pleasurable fulfillment. That is, the consumer senses that consumption fulfills some need, desire, goal, or so forth and that this fulfillment is pleasurable. Thus, satisfaction is the consumer's sense that consumption provides outcomes against a standard of pleasure versus displeasure. For satisfaction to affect loyalty, frequent or cumulative satisfaction is required so that individual satisfaction episodes become aggregated or blended. As will be argued here, however, more than this is needed for determined loyalty to occur. The consumer may require movement to a different conceptual plane in all likelihood, one that transcends satisfaction.

\section{RESEARCH METHODOLOGY}

The main purpose of this study is to clarify the concepts of switching costs and customer loyalty and to identify their dimensions and empirically seek to determine their intereffect. So that we can focus our analytical to determine the problems between switching cost problems and customer loyalty problems and we can focusing our effort in a right place, finally, is to be more effective and efficient in making a decision. The analysis model the author used for switching costs and customer loyalty research is combination between analytical analysis, through statistic test, and descriptive analysis, through table, or diagram along with the explanations.

The authors took sources from the journal of marketing. The model that authors used in this research of marketing is came from the empirical observations about market behavior, based on facts that existed and from the relationship between one variable with another variables. Those model is also could came from the existed theory or literature, managerial experience, evaluation, or facts concluding from the law of nature that had already known.

This consumer survey was conducted via e-mail and directly finding at the public place but users were randomly targeted. The e-mail questionnaire was sent to 20 users and 130 other fill directly in the place. We spare at several place (Senayan City, Plaza Senayan, Blok M Plaza (consist of population in many area (east, west, south, north and center Jakarta), Binus Business School, Trisakti University, Moestopo University, community in Jatibening South of Bekasi, several office, and others.

The questionnaire was made of 29 simple questions, all of them related to switching costs and customer loyalty. Consumers were given 1 week to respond. 150 respondents responded to the questionnaires, which uncounted for $94 \%$ response rate.

\section{DATA ANALYSIS}

Fornell (1992) was one of the first authors to consider switching costs, adding them to consumer satisfaction in the customer loyalty function. Reviews of literature suggest that higher switching costs are positively related to customer loyalty (Ping 1993; Ping 1997). Jones and Sasser (1995) mention switching costs as one factor that determines the competitiveness of market environment, since high switching costs discourage changing from 
a current provider, thereby yielding less incentive for firms actively to compete. Bateson and Hoffman (1999) suggest that as customer satisfaction is strongly linked to impressions of performance, satisfaction and switching costs are assumed to be the most important antecedents of repurchase behaviors, or the intention to repurchase a product or service.

Switching costs interact with satisfaction to influence loyalty (Jones, Mothersbaugh and Beatty 2000; Olivia, Oliver and MacMillan 1992) and this relationship has been shown to hold among mobile phone customers in France (Lee, Lee and Feick 2001). On the basis of the above this is extended to operator cellular customers and it is argued that:

H1: The higher the level of switching costs exhibited by corporate customers of mobile telephony the stronger the level of loyalty.

The above hypothesis is hardly in doubt. What this research seeks to do is drill down further to obtain a deeper insight. Both the concept of switching costs and customer loyalty have tended to be insufficiently conceptualized. This research uses more elaborate conceptualizations of both constructs and investigates the effect of the dimensions of switching costs on those of customer loyalty. It is argued that the psychological and emotional discomfort costs that constitute relational switching costs are the most challenging for any customer to overcome. Among operator cellular, contractual switching costs are unlikely to provide insurmountable barriers. Moreover, in the trade-off between the two commodities of time and costs, it is often time that is at a premium with managers. Therefore, it is expected that informational switching costs are likely to represent a stronger barrier to switching than contractual costs. Of course, the position may be reversed among non corporate customers.

With the exception of Oliver (1996) there is little literature that links specific dimensions of switching costs with those of loyalty. Broadly, Oliver (1996) argues that "consumers operating only at the cognitive level are hypothesized to be most susceptible to switching caused by marketing overtures while those "fully integrated" consumers at the level of action loyalty are hypothesized to be least susceptible'. Oliver (1996) argues that cognitive loyalty is the lowest level of loyalty and on the basis of the earlier distinction between switching costs it is held that:

H1a: The higher the contractual switching costs exhibited by customers of mobile telephony the stronger their cognitive loyalty.

Oliver (1996) also argues that affective loyalty contains some involvement by the customer, which aspect is most salient at the conative stage of loyalty. A commitment comes from emotional involvement represented by relational switching costs. Hence:

H1b: The higher the relational switching cost exhibited by customers of mobile telephony the stronger their affective and conative loyalty.

Finally, Oliver (1996) holds that action loyalty includes routines and habit behaviors. The inertia brought about by time constraints on customers in one that impede switching, therefore:

H1c: The higher the informational switching costs exhibited by customers of mobile telephony the stronger their action loyalty.

This section is showing the results of data analysis evaluation, such as multiple regressions, correlation, $\mathrm{r}$ square, beta and level of significant from switching costs on customer loyalty, contractual switching cost on cognitive loyalty, and relational switching cost on affective and conative loyalty, informational switching cost on action loyalty. We are trying to answer the hypotheses 1 , by referring from the results of table data below. 
Table 3.Model Summary of Switching Costs and Customer Loyalty

\begin{tabular}{|c|c|c|l|l|l|}
\hline \multicolumn{6}{|l|}{ Model Summary } \\
\hline Model & $\mathrm{R}$ & $\begin{array}{l}\mathrm{R} \\
\text { Square }\end{array}$ & $\begin{array}{l}\text { Adjusted } \\
\text { Square }\end{array}$ & $\begin{array}{l}\text { Std. Error of the } \\
\text { Estimate }\end{array}$ \\
\hline 1 & $.457(\mathrm{a})$ & 0.209 & 0.203 & 0.4023517 & \\
\hline \multicolumn{2}{|l|}{ a. Predictors: (Constant), Switching Cost } \\
\hline
\end{tabular}

Table 4. Coefficients of Switching Costs and Customer Loyalty

\begin{tabular}{|c|c|c|c|c|c|c|}
\hline \multicolumn{7}{|c|}{ Coefficients(a) } \\
\hline \multirow{2}{*}{ Model } & & \multicolumn{2}{|c|}{$\begin{array}{l}\text { Unstandardized } \\
\text { Coefficients }\end{array}$} & \multirow{2}{*}{$\begin{array}{l}\text { Standardized } \\
\text { Coefficients } \\
\text { Beta }\end{array}$} & \multirow{2}{*}{$\mathrm{t}$} & \multirow{2}{*}{ Sig. } \\
\hline & & B & $\begin{array}{l}\text { Std. } \\
\text { Error }\end{array}$ & & & \\
\hline \multirow[b]{2}{*}{1} & (Constant) & 3.321 & 0.180 & & 18.432 & 0.000 \\
\hline & $\begin{array}{l}\text { Switching } \\
\text { Cost }\end{array}$ & 0.297 & 0.049 & 0.457 & 6.055 & 0.000 \\
\hline
\end{tabular}

The score of significant level from this correlation is 0.000 (see table 4.15), if the score of significant is less than 0.05 , and then there is a significant relation between variables. Moreover, the score of significant is 0.000 , which mean $0.000<0.05$, and it is proofing a significant relation between switching costs and customer loyalty.

Hypotheses:

$\mathrm{H}_{0}: \mathrm{b}=0$ (There's no linier relation between switching costs and customer loyalty) $\mathrm{H}_{1}: \mathrm{b} \neq 0$ (There's a linier relation between switching costs and customer loyalty)

The score of significant in Table 4is 0.000 , which is the value is less than 0.05 . Because of sig. $<\alpha$ than $\mathrm{H}_{0}$ is rejected and $\mathrm{H}_{1}$ accepted, which mean there is a linier relation between switching costs and customer loyalty. In addition, inside Table 3 we can see the score of $\mathrm{R}^{2}=0.209$. Which mean the impact of switching costs on customer loyalty is about $20.9 \%$, and the other percent is the impact of other variable. Both of the score of significant in Table 4is 0.000 , which is the value is less than 0.05 . Which mean the constant and switching costs coefficient regression is significant. table data below.

We are trying to answer the hypotheses $1 \mathrm{a}$, by referring from the results of 
Table 5. Model Summary of Contractual Switching Costs and Cognitive Loyalty

\begin{tabular}{|c|c|c|c|l|l|}
\hline \multicolumn{6}{|c|}{ Model Summary } \\
\hline Model & $\mathrm{R}$ & R Square & $\begin{array}{l}\text { Adjusted } \\
\text { Square }\end{array}$ & $\begin{array}{l}\text { Std. Error of the } \\
\text { Estimate }\end{array}$ \\
\hline 1 & $.147(\mathrm{a})$ & 0.022 & 0.015 & 0.738 \\
\hline \multicolumn{2}{|r|}{ a. Predictors: (Constant), Contractual Switching Cost } \\
\hline
\end{tabular}

Table 6. Coefficient of Contractual Switching Costs and Cognitive Loyalty

\begin{tabular}{|c|c|c|c|c|c|c|}
\hline \multicolumn{7}{|c|}{ Coefficients(a) } \\
\hline \multirow[t]{2}{*}{ Model } & & \multicolumn{2}{|c|}{$\begin{array}{l}\text { Unstandardized } \\
\text { Coefficients }\end{array}$} & \multirow{2}{*}{$\begin{array}{l}\text { Standardized } \\
\text { Coefficients } \\
\text { Beta }\end{array}$} & \multirow[t]{2}{*}{$\mathrm{t}$} & \multirow[t]{2}{*}{ Sig. } \\
\hline & & $\mathrm{B}$ & Std. Error & & & \\
\hline \multirow[b]{2}{*}{1} & (Constant) & 4.746 & 0.208 & & 22.775 & 0.000 \\
\hline & $\begin{array}{l}\text { Contractual } \\
\text { Switching } \\
\text { Cost }\end{array}$ & 0.097 & 0.055 & 0.147 & 1.758 & 0.081 \\
\hline
\end{tabular}

We can see the score of $\mathrm{R}^{2}=0.022$ in Table 4.18 . Which mean the impact of contractual switching costs on cognitive loyalty is about $2.2 \%$, and the other percent is the impact of other variable. The score of significant of constant in Table 6 is 0.000 and the score of significant of contractual switching costs is 0.081 , which is the value of constant is less than 0.05 . Which mean the constant coefficient regression is significant. Moreover, the value of contractual switching costs is over 0.05 , which mean the contractual switching costs coefficient regression is not significant.

We are trying to answer the hypotheses $1 \mathrm{~b}$, by referring from the results of table data below.

Table 7. Model Summary of Relational Switching Costs on Affective and Conative Loyalty

\begin{tabular}{|l|l|l|l|l|}
\hline \multicolumn{5}{|c|}{ Model Summary } \\
\hline Model & $\mathrm{R}$ & R Square & $\begin{array}{l}\text { Adjusted R } \\
\text { Square }\end{array}$ & $\begin{array}{l}\text { Std. Error of } \\
\text { the Estimate }\end{array}$ \\
\hline 1 & $.510(\mathrm{a})$ & 0.260 & 0.254 & 0.542 \\
\hline \multicolumn{4}{|r|}{ a. Predictors: (Constant), Relational Switching Cost } \\
\hline
\end{tabular}

In addition, inside Table 7 we can see the score of $\mathrm{R}^{2}=0.260$. Which mean the impact of relational switching costs on affective and conative loyalty is about $26 \%$, and the other percent is the impact of other variable. Both of the score of significant in Table 8 is 0.000 , which is the value is less than 0.05 . Which mean the constant and relational switching costs coefficient regression is significant. 
Table 8. Coefficient of Relational Switching Costs on Affective and Conative Loyalty

\begin{tabular}{|c|c|c|c|c|c|c|}
\hline \multicolumn{7}{|c|}{ Coefficients(a) } \\
\hline \multirow[t]{2}{*}{ Model } & & \multicolumn{2}{|c|}{$\begin{array}{l}\text { Unstandardized } \\
\text { Coefficients }\end{array}$} & $\begin{array}{l}\text { Standardized } \\
\text { Coefficients }\end{array}$ & \multirow[t]{2}{*}{$\mathrm{t}$} & \multirow[t]{2}{*}{ Sig. } \\
\hline & & $\mathrm{B}$ & Std. Error & Beta & & \\
\hline \multirow[b]{2}{*}{1} & $($ Constant $)$ & 2.112 & 0.288 & & 7.342 & 0.000 \\
\hline & $\begin{array}{l}\text { Relational } \\
\text { Switching Cost }\end{array}$ & 0.526 & 0.075 & 0.510 & 6.984 & 0.000 \\
\hline
\end{tabular}

We are trying to answer the hypotheses $1 \mathrm{c}$, by referring from the results of table data below.

Table 9. Model Summary of Informational Switching Costs and Action Loyalty

\begin{tabular}{|c|c|c|c|c|}
\hline \multicolumn{4}{|c|}{ Model Summary } \\
\hline Model & $\mathrm{R}$ & $\begin{array}{l}\mathrm{R} \\
\text { Squar } \\
\mathrm{e}\end{array}$ & $\begin{array}{l}\text { Adjusted } \\
\text { Square }\end{array}$ & Std. Error of the Estimate \\
\hline 1 & $.062(\mathrm{a})$ & 0.004 & -0.003 & 0.6527 \\
\hline \multicolumn{4}{|l}{ a. Predictors: (Constant), Informational Switching Cost } \\
\hline
\end{tabular}

Table 10. Coefficient of Informational Switching Costs and Action Loyalty

\begin{tabular}{|c|c|c|c|c|c|c|}
\hline \multicolumn{7}{|c|}{ Coefficients(a) } \\
\hline \multirow[t]{2}{*}{ Model } & & \multicolumn{2}{|c|}{$\begin{array}{l}\text { Unstandardized } \\
\text { Coefficients }\end{array}$} & $\begin{array}{l}\text { Standardized } \\
\text { Coefficients }\end{array}$ & \multirow[t]{2}{*}{$\mathrm{t}$} & \multirow[t]{2}{*}{ Sig. } \\
\hline & & $\mathrm{B}$ & Std. Error & Beta & & \\
\hline \multirow[b]{2}{*}{1} & (Constant) & 4.108 & 0.247 & & 16.630 & 0.000 \\
\hline & $\begin{array}{l}\text { Informational } \\
\text { Switching } \\
\text { Cost }\end{array}$ & 0.051 & 0.069 & 0.062 & 0.736 & 0.463 \\
\hline
\end{tabular}

In addition, inside Table 9 we can see the score of $\mathrm{R}^{2}=0.004$. Which mean the impact of informational switching costs on action loyalty is about $0.4 \%$, and the other percent is the impact of other variable. The score of significant of constant in Table 10 is 0.000 and the score of significant of informational switching costs is 0.463 , which is the value of constant is less than 0.05 . Which mean the constant coefficient regression is significant. Moreover, the value of informational switching costs is over 0.05 , which mean the informational switching costs coefficient regression is not significant. 


\section{CONCLUSION}

Our research has been clarified the concept of switching costs which is the onetime costs that customers associate with the process of switching from one provider to another (see Burnham, Frels and Mahajan (2003)). Moreover, customer loyalty, which is a deeply held commitment to re-buy or repatronize a preferred product/service consistently in the future, thereby causing repetitive same brand or same brand-set purchasing despite situational influences and marketing efforts having the potential to cause switching behavior (see Oliver's (1997)). In addition, our research has been proving that the costs that customers in mobile telephony industry associate with the process of switching from one provider to another is a significant factor in their loyalty in mobile telephone services that they have used.

Moreover, our research has been showing the dimension of switching costs that is informational switching cost, contractual switching costs and relational switching cost. Where informational switching costs is principally involve the spending of time and money and consist of economic risk, learning and set-up overheads. Contractual switching costs engage the loss of financially quantifiable assets and consist of benefit loss and monetary loss. Moreover, relational switching costs involve psychological or emotional worry due to the loss of characteristics and breaking of bonds, and consist of individual affiliation loss and brand association.

And the dimension of customer loyalty is cognitive loyalty, conative loyalty, affective loyalty and action loyalty. Cognitive loyalties were loyalty based on brand belief only. Conative loyalty is a loyalty state that contains what, at first appears to be the deeply held commitment to buy noted in the loyalty definition. Affective loyalty is a liking or attitude toward the brand has developed based on cumulatively satisfying usage occasions. Moreover, action loyalty is commitment to the action of re-buying or re-using the product or services.

There is a same result between the result in main journal and our research that indicate, the more efforts or costs that customers in mobile telephony must do to switch to the other service providers is the more customers do not want to switch to the other services provider or the more customer will loyal to their current service provider. In addition, there is a different result between our main journal results and our research results, which is the result of the contractual switching costs and informational switching costs in our research is rejected, this may caused by the culture of industry of service providers in Indonesia and the culture of industry of service providers in Australia. In Australia, service provider gives a free mobile phone to their customer with contract in periodic time. Nevertheless, in our country, there is no contract like that in telecommunications business in Indonesia. So this is probably the reason why we have different results.

The results extend the support for a link between higher switching costs and stronger level of loyalty to corporate customers of mobile phone firms. Moreover, the findings provide understanding of the interplay between switching costs and loyalty. This is useful in the initial elaboration of theory and gives a useful insight to management.

Results provide rejected for a link between contractual switching costs and cognitive loyalty. Furthermore, the findings give an understanding of the relationship between contractual switching costs and cognitive loyalty. Those contractual switching costs have same direction with cognitive loyalty but the correlation between variables is too weak, or the impact of contractual switching costs on cognitive loyalty is very low. This is useful in the early 
explanation of theory and gives a useful insight to management. It is not effective if management wants to pretend their customers, and they do an improvement in their contractual switching costs activity.

Results provide support for a link between relational switching costs and affective and conative loyalty to corporate customers of mobile phone firms. Which mean the relational switching costs is the stronger influence in the all of activity of switching costs. This is useful insight to management. The result shows us, that it is effective if management wants to pretend their customers with doing an improvement in their marketing efforts on the relational switching costs activity.

Results provide rejected for a link between informational switching costs and action loyalty. Furthermore, the finding gives an understanding of the relationship between informational switching costs and action loyalty. Those informational switching costs have same direction with action loyalty but the correlation between variables is the weakest correlation between any variables of switching costs, or the impact of informational switching costs on action loyalty is the lowest impact comparing with the other variables. The result gives a very useful insight to management and the result try to telling us that it will not effective if management wants to pretend their customers with doing an improvement in their relational switching costs activity.

\section{REFERENCES}

Aaker, David A. (1992). The Value of Brand Equity. Journal of Business Strategy 13 (July/August):27-32

Ahuvia, Aaron. (1992). For the Love of Money: Materialism and Product lover. In Floyd Rudmin and Marsha Richins. (Eds.), Meaning, Measure, and Morality of Materialism, Provo, UT: Association for Consumer Research, 88-98.

Alba, Joseph W. \& J. Wesly Hutchinson. (1987). Dimensions of Consumer Expertise. Journal of Consumer Research 13 (March): 411-454

Caruana, Albert. (2004). The Impact of Switching Costs on Customer Loyalty: A Study among Corporate Customers of Mobile Telephony. Journal of Targeting, Measurement and Analysis for Marketing. 12 (3): 256-268

Anderson, E. \& MaSullivan, M.W. (1993). The antecedents and consequences of customer satisfaction for firms. Marketing Science, Vol. 12 No. 2, pp. 25-43.

Anderson, E., Fornell, C. \& Lehmann, D.R. (1994). Customer satisfaction, market share and profitability: findings from Sweden. Journal of Marketing, Vol. 58, July, pp. 53-66.

Anderson, Eugene \& Mary W. Sullivan. (1993). The Antecedents and Consequences of Customer Satisfaction for Firms. Marketing Science 12 (spring): 125-143 
Anderson, James C. \& David W. Gerbing. (1988). Structural Equation Modeling in Practice: A Review and Recommended Two-Step Approach. Psychological Bulletin 103 (3): 411-423

Bansal, Harvir S. \& Shirley F.Taylor. (1999a). Beyond Service Quality and Customer Satisfaction: Investigating Additional Antecedents of Service-Provider Switching Intentions. In Develompents in Marketing Science, Vol 22. Ed. Charles H. Noble. Coral Gabels, FL: Academy of Marketing Science, 75-82

Bansal, Harvir S. \& Shirley F.Taylor. (1999b). The Service-Provider Switching Model (SPSM): A Model of Consumer Switching Behavior in the Service Industry. Journal of Service Research 2:200-218

Bansal, Harvir S. \& Shirley F.Taylor. (2002). Investigating Interactive Effects in the Theory of Planned Behavior in a Service-Provider Switching Context. Psychology \& Marketing 19 (5): 407-425

Bansal, Shirley F.Taylor \& Yannik St. James. (2005). Migrating to a New Service Providers: Toward a Unifying Framework of Consumer Switching Behavior. Academy of Marketing Science 33 (1): 96-115

Bateson, J. E. G, \& K. D. Hoffman (1999). Management services marketing text and readings. $4^{\text {th }}$ edition. Fort Worth: The Dryden press.

Bejou, David \& Adrian Palmer. (1998). Service Failure and Loyalty: An Exploratory Empirical Study of Airline Customers. Journal of Service Marketing 12 (1): 7-22

Belk. Russell W. (1988). Possessions and the Extended self. Journal of Consumer Research, 15 (September), 139-68.

Bettman, James R. (1973). Perceived Risk and Its Components: A Model and Emoirical Test. Journal of Marketing Research 10 (May): 184-190.

Bloom, B. L., Asher, S. J. \& White, S. W. (1978). Marital disruption as stressor: A Review and Analysis. Psychological Bullletin, 85:867-894

Bogue, D.J. (1969). Principles of Demography. New York: John Wiley.

Bogue, D.J. (1977). A Migrant's-Eye View of The Cost and Benefits of Migration to a Metropolis. In Internal Migration: A Comparative Perspective. New York: Academic Press, $167-182$

Boorstin, Daniel J. (1973). The Americans: The Democratic Experience New York: Random House.

Boyle, Paul, Keith Halfacree, \& Vaughan Robinson. (1998). Exploring Contemporary Migration. New York: Longman. 
Burnham T. A., J. K. Frels \& V. Mahajan. (2003). Consumer switching cost: A typology, antecedents and concequences. Journal of the Academy of Marketing Science, Vol 31, No. 2, pp. 109-126.

Chaudhuri, Arjun \& Morris B. Holbrook. (2001). The Chain of Effects From Brand Trust and Brand Affect to Brand Performance: The Role of Brand Loyalty. Journal of Marketing 65 (2): 81-93.

Churchill, Gilbert A. Jr. (1979). A Paradigm for Developing Better Measures of Marketing Constructs. Journal of Marketing Research 16 (February) : 64-73

Clark, David E. \& Thomas A. Knapp. (1996). Personal and Location Specific Characteristics and Elderly Interstate Migration. Growth and Change 27 (3): 327-352.

Cooper, Robert G. (1993). Winning at New Products: Accelerating the Process from idea to Launch. $2^{\text {nd }}$ ed. Reading, MA: Addison-Wesley.

Cronin, J, Joseph, Michael K. Brady, \& G. Tomas M. Hult. (2000). Assessing the Effects of Quality, Value, and Customer Satisfaction on Consumer Behavioral Intentions in Service Environments. Journal of Retailing 76 (2): 193-218

Dabholkar, Pratibha A. \& Simon Walls. (1999). Service Evaluation and Switching Behavior for Experiential Services: An Empirical Test of Gender Differnces Within a Broader Conceptual Framework. Journal of Consumer Satisfaction, Dissatisfaction, and Complaining Behavior 12:123-137

De Jong, Gordon F. \& James T. Fawcett. 1981. Motivations for Migration: An Assessment and a Value Expectancy Research Model. In G. F. De Jong \& R. W. Gardner. Elmsford, (Eds.), Migration Decision Making: Multidisciplinary Approaches to Microlevel Studies in Developed and Developing Countries. NY: Pergamon.

Dekimpe, Marnik G., Jan-Benedict E.M. Steenkamp. Martin Mellens. \& Piet Vanden Abeele. (1997). Decline and Variability in Brand loyalty. International Journal of Research in Marketing. 14 (December), 405-20.

Deming, W. Edwards .(1986). Out of the Crisis. Cambridge, MA: Massachusetts Institute of Technology Center for Advanced Engineering Study.

Desarbo, Wayne S., Lenard Huff, Marcelo M. Rolandelli, \& Jungwhan Choi. (1994). On the Measurement of Perceived Service Quality: A Conjoint Analysis Approach. In Roland T. Rust and Richard L. Oliver. (Eds.), Service Quality: New Directions in Theory and Practice. Thousand Oaks, CA: Sage Publications, 201-22.

Dick, Alan S. \& Kunal Basu. (1994). Customer Loyalty: Toward an Integrated Conceptual Framework. Journal of the Academy of Marketing Science, 22 (Winter). 99-113. 
Dorigo, Guido \& Waldo Tobler. (1983). Push-Pull Migration Laws. Annals of the Association of American Geographers 73 (1): 1-17

Dowling, G.R. \& Uncles, M. (1997). Do customer loyalty programs really work?. Sloan Management Review, Summer, pp. 71-82.

East, Robert \& Kathy Hammond. (1996). The Erosion of Repeat-Purchase Loyalty. Marketing Letters, 7 (March), 163-71.

Eliashberg, Jehoshua \& Thomas S. Robertson. (1988). Dynamic Competition With Switching Costs. RAND Journal of Economics 19 (Spring): 123-137

Fornell, C. (1992). A national customer satisfaction barometer: the Swedish experience. Journal of Marketing, Vol. 56, January, pp. 6-21.

Fornell, C. \& Wernerfelt, B. (1987). Defensive marketing strategy by customer complaint management: a theoretical analysis. Journal of Marketing Research, Vol. 24, November, pp. 337-46.

Fournier, Susan. (1998). Consumers and Their Brands: Developing Relationship Theory in Consumer Researcher. Journal of Consumer Research. 24 (March). 343-73.

Friedman, Monroe. Piet Vanden Abeele, \& Koen De Vos. (1993). Boorstin's Consumption Community Concept: A Tale of Two Countries. Journal of Consumer Policy, 16 (1), $35-60$.

Garbarino, Ellen \& Mark S. Johnson. (1999). The Different Roles oif Satisfaction, Trust, and Commitment in Customer Relationships. Journal of Marketing 62 (2) : 70-87

Germani, G. (1965). Migration and Acculturation. In Handbook for Social Research in Urban Areas. Ed. Philip M. Hauser. Brussels, Belgium: UNESCO, 159-178

Goodwin, Cathy. (1997). Communality as a Dimension of Service Relationships. Journal of Consumer Psychology, 5 (4), 387-415.

Gremler, D. D. (1995). The Effect of Satisfaction, Switching Costs and Interpersonal Bonds on Service Loyalty. Doctoral dissertation, Arizona State University

Guiltnan, Joseph P. (1989). A Classification of Switching Costs With Implications for Relationship Marketing. In Terry L. Childers. Richard P. Bagozzi, And J. Paul Peter (Eds), 1989 AMA Winter Educators Conference: Marketing Theory and Practice.. Chicago: American Marketing Association, 216-220

Heide, Jan B. \& Allen M. Weiss. (1995). Vendor Consideration and Switching Behavior for Buyers in High-Technology Markets. Journal of Marketing 59 (July): 30-43 
Hennig-Thurau, Thorsten, Kevin P. Gwinner \& Dwayne Gremler. (2002). Understanding Relationship Marketing Outcomes. Journal of Service Research 4 (3): 230-247

Hess, Ronald L., Jr,. Shankar Ganesan, \& Noreen N. Klein. (2003). The Impact of Relationship Factors on Customer Satisfaction. Journal of the Academy of Marketing Science 31 (2): 127-145

Higgins, Kevin T. (1997). Coming of Age: Despite Growing Pains, Customer Satisfaction Measurement Continues to Evolve. Marketing News. 31 (October 27), 1, 12.

Hirschman, A.O. (1970). Exit, Voice and Loyalty Responses to Declines in Firms, Organizations and States, Harvard University Press, Cambridge, MA.

http://www.indonesiatech.com/telco-in-indonesia/ Last Accesed 29-10-2007

Irianto, Agus. (2004). Statistik: Konsep Dasar \& Aplikasinya. Jakarta: Kencana Prenada Media.

Jackson, Barbara B. (1985). Winning and Keeping Industrial Customers. Lexington, MA: Lexington Books.

Jackson, John A. (1986). Migration. In Aspects of Modern Sociology: Social Processes. London and New York: Longman.

Jacoby, Jacob \& Robert W. Chestnut. (1978). Brand Loyalty. New York: John Wiley \& Sons, Jones.

Jones, Michael A, David L. Mothersbaugh, \& Sharon E. Beatty. (2000). Switching Barriers and Repurchase Intentions in Service. Journal of Retailing 72:259-274

Jones, T.O. \& Sasser, W.E. (1995). Why satisfied customer defects. Harvard Business Review, November-December, pp. 88-99.

Kalyanaram, Gurumurthy \& John D.C. Little. (1994). An Empirical Analysis of Latitude of Price Acceptance in Consumer Package Goods. Journal of Consumer Research. 21 (December). 408-18.

Karakaya, Fahri \& Michael J. Stahl. (1989). Barriers to Entry and Market Decisions in Consumer and Industrial Goods Markets. Journal of Marketing 53 (April): 80-91

Keaveney, S. M. (1995). Customer switching behavior in service industries: An exploratory study. Journal of Marketing, Vol. 59, No. 2, pp. 71-82.

Kerin, Roger A., P. Rajan Varadarajan, \& Robert A. Peterson. (1992). First-Mover Advantage: A Synthesis, Conceptual Framework, and Research Proporsitions. Journal of Marketing 56 (october): 33-52 
Klemperer, P. (1987). Market with consumer switching costs. The Quarterly Journal of Economics, Vol. 102, pp. 375-394.

Klemperer, Paul. (1995). Competition When Consumers Have Switching Costs: An Overview With Applications to Industrial Organization, Macro-economics, and International Trade. Review of Economic Studies 62:515-539

Kuhl, Julius \& Jurgen Beckmann. (1985). Historical Perspectives in the Study of Action Control. In Julius Kuhl \& Jurgen Beckmann, (Eds), Action Control: From Cognition to Behavior. Berlin: Springer-Verlag, 89-100.

Kumar, Nirmalya, Lois W Stern, \& Ravi S. Achrol. (1992). Assesing Reseller Performance From the Perspective of The Supplier. Journal of Marketing Research 24 (May): 238253

Lee, Everett S. (1966). A Theory of Migration. Demoghraphy 3:47-57.

Lee, J., Janghyuk Lee \& Lawrence Feick. (2001). The impact of switching cost on the customer satisfaction-loyalty link: Mobile phone service in France. Journal of Services Marketing, Vol. 15, No. 1, pp. 35-48.

Lewis, G. J. (1982). Human Migration: A Geographocal Perspective. London and Canberra, Australia: Croom Helm

Levine, David M., David Stephan, Timothy C. Krehbiel, \& Mark L. Berenson. (2005). Statistics for Managers: Using Microsoft ${ }^{\circledR}$ Excel. USA: Pearson Education.

Longino, C. F., Jr. (1992). The Forest and the Trees: Micro-level Consideration in the Study of Geographic Mobility inOld Age. In A. Rogers. (Eds), Elderly Migration and Population Redistribution. London: Bellhaven, 23-34

McCracken, Grant. (1986). Culture and Consumption: A Theoritical Account of the Structure and Movement of the Cultural Meaning of Consumer Goods. Journal of Consumer Research 13 (June):71-84.

McDougall, Gordon H. G. \& Terrence Levesque. (2000). Customer satisfaction With Services: Putting Percieved Value Into the Equation. Journal of Service Marketing 14 (5): 392-410.

Miller, Rowland S. (1997). Inattentive and Contented: Relationship Commitment and Attention to Alternatives. Journal of Personality and Social Psychology, 73 (October). 758-66.

Moon, Bruce. (1995). Paradigms in Migration Research: Exploring 'Moorings' as a Schema. Progress in Human Geography 19 (4): 504-524 
Morgan, Michael S. \& Chekitan S. Dev. (1994). An Empirical Study of Brand Switching for a Retail Service. Journal of Retailing. 70 (Fall), 267-82.

Murray, Sandra L., John G. Holmes., \& Dale W. Griffin. (1996). The Benefits of Positive Illusions: Idealization and the Construction of Satisfaction in Close Relationships. Journal of Personality and Social Psychology, 70 (January), 79-98.

Newman. Joseph W. \& Richard A. Werbel. (1973). Multivariate Analysis of Brand Loyalty for Major Household Appliances. Journal of Marketing Research. 10 (November), 404-409.

Oliva, Terence A., Richard L. Oliver. \& Ian C. MacMillan. (1992). A Catastrophe Model for Developing Service Satisfaction Strategies. Journal of Marketing. 56 (JuIy), 83-95.

Oliver, R. L. (1996). Satisfaction: A Behavioural perspective on the Consumer. New York: McGraw Hill.

Oliver, Richard L. (1980). A Cognitive Model of the Antecedents and Consequences of Satisfaction Decisions. Journal of Marketing Research, 17 (November), 460-69.

Oliver, Richard L. (1997). Satisfaction: A Behavioral Perspective on the Consumer. New York: Irwin//McGraw-Hill.

Oliver, Richard L. (1999). Whence Consumer Loyalty?. Journal of Marketing, 63:33-44

Olivia, T. A., R. L. Oliver \& L. C. MacMillan. (1992). A Catastrophic Model For Developing Services Satisfaction Strategies. Journal of Marketing, 56 (3):83-95

Parasuraman, A., Zeithaml, V.A. \& Berry, L.L. (1988). SERVQUAL: a multiple-item scale for measuring consumer perceptions of service quality. Journal of Retailing, Vol. 64 No. 1, pp. 12-40.

Pedersen \& Nysveen (2001). Shopbot banking: An experimental study of customer satisfaction and loyalty. Foundation for Research in Economics and Business Administration. Financed by The Research Council of Norway, Telenor ASA, the media group Schibsted ASA and the bank Sparebanken Hedmark."

Peters, T. (1988). Thriving on Chaos, Alfred A. Knopf, New York, NY.

Ping, R. A. Jr. (1997). Voice in Business to Business Relationships: Costs of Exit and Demographic antecedents. Journal of Retailing 73 (2): 261-281

Ping, Robert A., Jr. (1993). The Effects of Satisfaction and Stuctural Constraints on Retailing Exiting, Voice, Loyalty, Opportunism, and Neglect. Journal of Retailing 69 (3): 320352 
Ping, Robert A.. Jr. (1994). Does Satisfaction Moderate the Association Between Alternative Attractiveness and Exit Intention in a Marketing Channel?. Journal of the Academy of Marketing Science, 22 (Fall). 364-71.

Porter, M. E. (1980). Competitive strategy: Techniques for analyzing industries and competitors. New York: Macmillan.

Pryor, Robin J. (1981). Integrating International and Internal Migration Theories. In Mary M. Kritz, Charles B. Keely, and Silvani M. Tomasi (Eds.), Global Trends in Migration: Theory and Research on International Population Movements, Staten Island, NY: Center for Migration Stidies, 100-129

Reichheld F.F. (1996). The Loyalty Effect: The Hidden Force behind Growth, Profits and Lasting Value. Harvard Business School Press, Boston, MA.

Reichheld, F. F. \& W. E Sasser jr. (1990). Zero defections: Quality comes to services. Harvard Business Review, Vol 68, No. 5, pp. 105-111.

Richmond, Anthony H. (1988). Sociological Theories of International Migration: The Case of Refugees. Current Sociology 36:7-25

Rust, R.T. \& Zahorik, A.J. (1993). Customer satisfaction, customer retention, and market share. Journal of Retailing, Vol. 69 No. 2, Summer, pp. 193-215.

Rust, R.T., Zahorik, A.J. \& Keiningham, T.L. (1995). Return of quality (ROQ): making service quality financially accountable. Journal of Marketing, Vol. 59, April, pp. 5870.

Sambandam, Rajan \& Kenneth R. Lord. (1995). Switching Behavior in Automobile Markets: A Consideration-Sets Model. Journal of the Academy of Marketing Science. 23 (Winter), 57-65.

Samuelson, William \& Richard Zeckhauser. (1988). Status Quo Bias in Decision Making. Journal of Risk and Uncertainty 1:7-59

Schouten, John W. \& James H. McAlexander. (1995). Subcultures of Consumption: An Ethnography of the New Bikers. Journal of Consumer Research. 22 (June), 43-61.

Shapiro, Carl \& Hal R. Varian. (1999). The art of standard war. California Management Review, Berkley, Vol. 41, No. 42, pp. 8-32.

Sharma, Neeru \& Paul G. Patterson. (2000). Switching Costs, Alternative Attractiveness and Experience as Moderators of Relationship Commitment in Professional, Consumer Services. International Journal of Service Industry Management 11 (5):470-490

Sharp, Byron \& Anne Sharp. (1997). Loyalty Programs and Their Impact on Repeat-Purchase Loyalty Patterns. International Journal of Research in Marketing, 14 (December). 473-86. 
Shugan, Steven M. (1980). The Costs of Thinking. Journal of Consumer Research 7 (September): 99-111

Sirdermukh, Deepak, Jagdip Singh, \& Barry Sabol. (2002). Consumer Trust, Value, and Loyalty in Relational Exchanges. Journal of Marketing 66 (January): 15-37

Sivakumar. K. \& S. P. Raj. (1997). Quality Tier Competition: How Price Change Influences Brand Choice and Category Choice. Journal of Marketing 61 (JuIy), 71-84.

Stewart, Thomas A. (1997). A Satisfied Customer Isn't Enough. Fortune, 136 (July 21), 11213.

Stimson, Robert J. and John Minnery. (1998). Why People Move to the 'Sun-Belt': A Case Study Long-Distance Migration to the Gold Coast, Australia. Urban Studies 35 (2): 193-214

Sulaiman, Wahid. (2004). Analisis REGRESI Menggunakan SPSS: Contoh Kasus dan Pemecahannya. Yogyakarta: ANDI Yogyakarta.

Tellis, Gerard J. (1988). Advertising Exposure. Loyalty, and Brand Purchase: A Two-Stage Model of Choice. Journal of Marketing Research. 25 (May). 134-44.

Thibault, J. W. \& H. H. Kelley. (1959). The Social Psychology of Groups. New York: John Wiley \& Sons.

Tse, David K. \& Peter C. Wilton. (1988). Models of Consumer Satisfaction Formation: An Extension. Journal of Marketing Research, 25 (May). 204-12.

Tsuda, Takeyuki. (1999). The Motivation to Migrate: The Etnhic and Sociocultural Constitution of Japanese-Brazilian Return-Migration System. Economic Development and Cultural Change 49 (1): 1-31

Weiss, Allen M \& Jan B. Heide. (1993). The Nature of Organizational Search in High Technology Markets. Journal of Marketing Research 30 (May): 220-233

Wernerfelt, Birger. (1985). Brand Loyalty and Users Skills. Journal of Economic Behavior and Organizations 6:381-385

Wilson, David T. (1995). An Integrated Model of Buyer-seller Relationships. Journal of the Academy of Marketing Science, 23 (Fall), 335-45.

Wolpert, Julian. (1965). Behavioral Aspects of Decision to Migrate. Papers of the Regional Science Association 15:159-169.

Wolpert, Julian. (1966). Migration as an Adjustment to Environmental Stress. Journal of Social Issues 22:92-102

Wylie. Kenneth. (1993). Customer Satisfaction Blooms: Rivalry at Top Grows. Advertising Age. (October 18). S1-S5. 
Zeithaml, Valarie A., Leonard L. Berry, \& A. Parasuraman. (1996). The Behavioral Consequences of Service Quality. Journal of Marketing 60 (April): 31-46

Zeithaml, Valarie A. (1998). Consumer Perception of Price, Quality, and value: A Means-End Model and Synthesis of Evidence. Journal of Marketing 52 (July): 2-22 